\title{
Implementasi Simple Additive Weighting Untuk Monitoring Aktivitas Perkuliahan Dengan Menggunakan Radio Frequency Identification
}

\author{
Ashari Darmawan *) \\ *) Program Studi Sistem Informasi Universitas Andalas, Padang \\ Naskah Diterima : 3 April 2017; Diterima Publikasi : 13 Mei 2017
}

DOI: $10.21456 /$ vol7iss 1pp48-58

\begin{abstract}
Monitoring of learning activities has a very important role to improve the quality of education in University. The research aims to develop a monitoring system of learning activities in real time by using simple additive weighting and radio frequency identification technology. A simple additive weighting method is used to determine the weighting of each criterion involved in the system, while radio frequency identification technology is used electronically to identify and store learning activity information. Monitoring system built using learning activities data in the room and lecturer activities using radio frequency identification tag in real time. The results of the system include the recording of monitoring data of lecturing activities that produce lecturer attendance reports on each class in real time, thus making efficient the time, effort and cost. The system also produces a ranking of lecturer discipline on each of the criteria that gives the difference of outcomes among the consistent lecturers present on schedule with inconsistent lecturers present on schedule. The results of monitoring of lecture activities can be used for university leaders as a decision-making material quickly based on actual data in real time to improve the quality of the learning process.
\end{abstract}

Keywords: Simple Additive Weighting; Radio Frequency Identification; Learning; Monitoring Systems

\begin{abstract}
Abstrak
Monitoring aktivitas perkuliahan mempunyai peran yang sangat penting terhadap peningkatan kualitas pendidikan di Perguruan Tinggi. Penelitian ini bertujuan untuk mengembangkan sistem monitoring aktivitas perkuliahan secara real time dengan menggunakan simple additive weighting dan teknologi radio frequency identification. Metode simple additive weighting digunakan untuk menentukan pembobotan dari setiap kriteria yang dilibatkan dalam sistem, sedangkan teknologi radio frequency identification digunakan secara elektronik untuk mengidentifikasi dan menyimpan informasi aktivitas perkuliahan. Sistem monitoring yang dibangun memakai data aktivitas perkuliahan di ruangan dan aktivitas dosen menggunakan tag radio frequency identification secara real time. Hasil dari sistem berupa perekaman data monitoring aktivitas perkuliahan yang menghasilkan laporan kehadiran perkuliahan dosen pada masing-masing kelas secara real time, sehingga mengefisiensikan waktu, tenaga dan biaya. Sistem juga menghasilkan perangkingan tingkat kedisiplinan dosen pada masing-masing kriteria yang memberikan perbedaan hasil antara dosen yang konsisten hadir sesuai jadwal dengan dosen yang tidak konsisten hadir sesuai jadwal. Hasil monitoring aktivitas perkuliahan dapat digunakan bagi pimpinan perguruan tinggi sebagai bahan pengambilan keputusan dengan cepat berdasarkan data aktual secara real time untuk meningkatan mutu proses perkuliahan.
\end{abstract}

Kata kunci: Simple Additive Weighting; Radio Frequency Identification; Perkuliahan; Sistem Monitoring

\section{Pendahuluan}

Penggunaan teknologi informasi pada suatu perguruan tinggi menjadi keharusan, sehingga perguruan tinggi dapat memenuhi harapan masyarakat, yang ditandai dengan menjadi lebih terbuka, fleksibel, dan kompetitif. Perguruan tinggi juga mampu menanggapi kebutuhan mahasiswa dengan mulai berpikir secara global dan menciptakan aliansi baru,

*) Penulis korespondensi: ashari.darmawan@gmail.com desain program baru, merestrukturisasi konsepsi mereka pada karakteristik lingkungan belajar. Disamping itu perguruan tinggi juga mampu membangun kembali konsepsi mereka pada nilai pengetahuan, dan mengembangkan kebijakan internal untuk mendorong inovasi, eksperimentasi, dan kreativitas dosen.

Masalah penting dari pembangunan sosial dan kemajuan teknologi berupa peningkatan mutu 
pendidikan. Pentingnya peningkatan mutu pendidikan tinggi pada saat ini disebabkan peningkatan daya saing dan kualitas hidup manusia (Glushak et al., 2015). Analisis komponen merupakan salah satu alat manajemen untuk memantau sistem pendidikan tinggi di tingkat makro dan mikro. Penerapan monitoring telah digunakan dalam sistem pendidikan secara luas untuk melihat dampak langsung yang timbul terhadap efektivitas mutu pendidikan serta dapat meningkatkan kualitas proses pendidikan (Bazhenov et al., 2015).

Pengambilan keputusan merupakan masalah penting bagi organisasi untuk menemukan alternatif terbaik dari alternatif yang layak. Pengambilan keputusan digunakan untuk memecahkan multi kriteria yang terdapat ketidakpastian dan ketidakjelasan. Simple Additive Weighting (SAW) merupakan sebuah metode pembobotan yang diterapkan untuk membuat ranking, dimana model berdasarkan $S A W$ memiliki hubungan preferensi relatif untuk memecahkan masalah menjadi lebih mudah dan efisien (Wang, 2015; Agarski et al., 2015). Dalam memecahkan masalah pengampilan keputusan yang kompleks terdapat aplikasi analisis multi kriteria yang cukup luas.

Metode SAW telah diterapkan pada sistem perangkingan di beberapa organisasi seperti perguruan tinggi untuk melakukan perangkingan mahasiswa yang berprestasi, dan lainnya. Metode pembobotan sederhana ini mempunyai keunggulan dapat melakukan analisa data secara lebih sederhana menggunakan pembobotan terhadap beberapa kriteria yang telah ditentukan Sistem perangkingan yang diterapkan pada lingkungan perguruan tinggi mendapat perhatian khusus karena memberikan kontribusi untuk lahirnya generasi baru peringkat, salah satu yang dapat meningkatkan seni pada keadaan saat ini, dengan mengintegrasikan informasi jenis baru dan menggunakan teknik peringkat baru (Daraioa et al., 2015).

Radio Frequency Identification (RFID) telah digunakan untuk perkembangan teknologi yang cukup terjangkau dan dapat digunakan secara luas. RFID merupakan identifikasi otomatis sebagai salah satu teknologi komputasi yang mampu berkomunikasi secara dua arah dan operasional sistem RFID mampu memberikan informasi dan / atau fungsi operasional (Roberts, 2006). Aplikasi RFID digunakan terus meningkat dalam industri yang berbeda. RFID juga dapat digunakan sebagai alat untuk meningkatkan kualitas pelayanan, kepuasan pelanggan, pangsa pasar, dan profitabilitas. Penerapan RFID di lingkungan kampus dapat meningkatkan kenyamanan dalam proses perkuliahan, meningkatkan kualitas pengajaran dan efisiensi administrasi (Chang et al., 2013).

Aktivitas perkuliahan yang tidak terkontrol dengan baik dapat berdampak pada mutu pendidikan, dimana rendahnya tingkat kedisiplinan dosen membuat interaksi komunikasi serta penyerapan ilmu oleh peserta didik dari dosen menjadi rendah dan kurang sempurna. Metode SAW yang digabungkan dengan teknologi Berdasarkan latar belakang tersebut maka perlu adanya teknologi RFID untuk monitoring aktivitas perkuliahan secara real time yang terjadi di ruang perkuliahan dan hasil data real time RFID akan diproses dengan pembobotan sederhana yang akan menghasilkan suatu kesimpulan sebagai pendukung keputusan dengan acuan untuk meningkatkan proses perkuliahan di masa yang akan datang.

Penelitian ini bertujuan untuk mengembangkan sistem monitoring aktivitas perkuliahan secara real time dengan menggunakan SAW dan teknologi RFID. Sistem ini digunakan untuk monitoring aktivitas perkuliahan meliputi kedisiplinan dosen, dan pelaporan aktivitas perkuliahan dosen guna peningkatan mutu pendidikan dengan memanfaatkan teknologi RFID dan metode SAW digunakan untuk membuat ranking kriteria yang dilibatkan dalam monitoring. RFID digunakan sebagai bahan pengambilan keputusan untuk mencari solusi dengan cara melakukan perangkingan tingkat kedisiplinan dosen serta pelaporan aktivitas perkuliahan yang terjadi di ruang perkuliahan dalam bentuk sistem monitoring perkuliahan.

\section{Kerangka teori}

\subsection{Radio Frequency Identification}

Radio Frequency Identification (RFID) telah bertahun-tahun digunakan sebagai teknologi dapat diandalkan untuk digunakan secara luas. Dari Electronic Article Surveillance (EAS) tentang keamanan pada penggunaan teknologi yang lebih canggih, RFID dipandang oleh beberapa orang sebagai pengganti untuk kode bar. Dengan meningkatnya penggunaan RFID menyebabkan meningkatnya kekhawatiran tentang privasi dan keamanan. Pekerjaan yang harus dilakukan sebelum $R F I D$ ada menjadikannya sebagai bar codes meskipun tempo perubahan teknologi meningkat dengan cepat (Roberts, 2006).

Area aplikasi awal RFID umumnya berada pada industri, seperti sektor ritel, manajemen supply chain (rantai suplai), manajemen gudang, logistik, manufaktur, aplikasi militer, dan sektor jasa juga menggunakan aplikasi RFID. Tujuan dari penelitian tersebut adalah untuk menyelidiki kemungkinan kegunaan $R F I D$ di industri perhotelan sebagai alat untuk meningkatkan kualitas pelayanan, kepuasan pelanggan, pangsa pasar, dan profitabilitas. Dengan cara ini, literatur kualitas layanan akan dibahas dan dimensi kualitas penting akan dipilih untuk analisa lebih lanjut. Setelah review singkat pada teknologi $R F I D$, aplikasi, ancaman di masa depan, dan peluang yang diberikan. Hipotesis studi kasus yang didefinisikan dan skenario adalah diilustrasikan berdasarkan atribut umum dari operasi manajemen hotel. Melalui analisis studi kasus, perubahan proses bisnis yang terkena dan kontribusi dari solusi berbasis 
RFID yang dibahas menurut dimensi kualitas layanan yang dipilih (Oztaysi et al., 2009).

Implementasi sistem RFID pada kampus digital dapat meningkatkan kenyamanan dalam lingkungan mengajar, kualitas pengajaran dan efisiensi administrasi. Ketika administrator memutuskan untuk menerapkan sistem RFID kampus digital, mereka sering menghadapi hal internal yang tak terduga dan faktor risiko eksternal serta kesulitan kesulitan. Oleh karena itu, penelitian tersebut mengusulkan sebuah model untuk membantu administrator dalam mengidentifikasi faktor-faktor penting risiko yang mempengaruhi inisiasi sistem $R F I D$ kampus digital, dan mengukur risiko agregatif dari implementasi sistem kampus digital RFID. Bobot penting dari faktor risiko dan peringkat kemungkinan terjadinya empat nilai risiko (tinggi, menengah, rendah dan tidak ada) ditentukan dengan menggunakan consistent fuzzy preference relations. Bobot prioritas relatif dari evaluator dianggap secara bersamaan dengan menggunakan metode pembobotan sederhana. Mengalikan bobot pentingnya faktor risiko, peringkat terjadinya kemungkinan nilai risiko dan bobot prioritas relatif dari evaluator, tingkat risiko agregatif dari menerapkan RFID sistem kampus digital berasal. Universitas di Taiwan digunakan untuk menunjukkan prosedur perhitungan metodologi yang diusulkan ini (Chang et al., 2013).

Penelitian tentang pemanfaatan teknologi dengan berbagai dampak memilih teknologi RFID sebagai salah satu cara yang mungkin untuk menghilangkan masalah yang dibahas. RFID adalah teknologi yang mengarah ke otomatisasi proses dan pembatasan tugas sederhana manusia. Penulis menyarankan pendekatan expert-analytic untuk menyelesaikan masalah tersebut. Pendekatan ini diterapkan di beberapa perusahaan manufaktur di Eropa. Itu menegaskan bahwa dampak skala teknologi melebihi implementasi $R F I D$. Pendekatan ini cepat dan merupakan pemikiran dari implementasi RFID. Pendekatan yang disebut ART (Assesment of RFID Technology) diverifikasi positif. Hasil yang memuaskan untuk perbandingan pro dan kontra RFID yang diimplementasikan dalam supply chains (rantai pasokan). Berdasarkan pada hasil yang dicapai, keputusan tentang analisis lanjutan yang lebih rinci dan desain sistem RFID, yang biasanya mahal dan memakan waktu, bisa dilakukan. Pendekatan ini menghasilkan tanda-tanda bagi perusahaan, jika RFID seharusnya dapat dipertimbangkan. Asumsi dari pendekatan yang umum dan dapat dengan mudah disesuaikan dengan teknologi lainnya. Ini penting terutama ketika membahas teknologi yang hampir sebanding dengan studi kasus atau yang dilaporkan sangat berbeda, sehingga perusahaan tidak bisa mengandalkan pengalaman dari organisasi atau bidang aplikasi lainnya. Kasus penggunaan pendekatan berkembang ketika skala dampak dari penerapan teknologi melebar dan tidak menyempit ke daerah pelaksanaan fisiknya (Gladysz dan Santarek, 2015).

Penelitian tentang pemanfaatan RFID untuk sistem administrasi sekolah berfokus pada menerapkan sistem otomasi / manajemen yang memudahkan pengawasan siswa dan mengurangi beban pada staf administrasi sekolah. Dalam penelitian ini sistem administrasi sekolah menggunakan RFID tag / pembaca. Sistem ini mampu mengidentifikasi orang secara otomatis, manajemen kelas/ laboratorium/ kehadiran perpustakaan, statis/ dinamis otorisasi, pengajuan peringatan/ pengumuman, penggunaan e-money, penerbangan dan pelaporan. Karena memberikan ketahanan dan jangka tahan lebih lama pada server yang strukturnya dirancang secara independen (Akpinar dan Kaptan, 2010).

Simple Additive Weighting (SAW) merupakan metode terkenal yang diterapkan dalam lingkungan fuzzy, tetapi memiliki kelemahan perkalian untuk menggeneralisasi $S A W$ di bawah lingkungan yang samar. Untuk mengatasi kelemahan perkalian, dimanfaatkan hubungan preferensi relatif yaitu dari hubungan fuzzy preference di lingkungan $S A W$ secara umum. Umumnya, hubungan preferensi fuzzy merupakan pilihan untuk memesan banyak pesanan. Namun, perbandingan berpasangan untuk menunjukkan hubungan preferensi fuzzy secara kompleks pada suatu operasi. Hubungan preferensi relatif meningkat pada bentuk relativitas preferensi yang masih samar, untuk menghindari membandingkan angka fuzzy pada pesan berpasangan dan pemesanan yang masih samar. Melalui hubungan preferensi relatif, kita bisa menggeneralisasi $S A W$ di bawah lingkungan fuzzy. Dikatakan bahwa dengan diusulkannya sebuah model berdasarkan $S A W$ dan hubungan preferensi relatif dapat mempermudah dan dan mempercepat memecahkan masalah (Wang, 2015).

Multi kriteria metode analisis memiliki aplikasi yang luas dalam memecahkan masalah pengambilan keputusan yang kompleks. Teknik untuk mengevaluasi berbagai jenis kriteria memungkinkan multi kriteria analisis untuk diterapkan dalam siklus hidup metode penilaian. Multi kriteria metodologi logika fuzzy bertujuan untuk melakukan kategori dampak pembobotan dan analisis sensitivitas dalam penilaian siklus hidup produk dan proses. Metodologi yang diusulkan untuk kategori dampak bobot mengintegrasikan pembuat keputusan dengan faktor subjektif dan kategori dampak standar pembobotan menggunakan sistem gangguan yang masih samar. Gangguan sistem memungkinkan relevansi bobot kategori yang berdampak subjektif dan standar untuk menjadi berubah dan memberikan pendekatan baru untuk pemodelan faktor pembobotan menggunakan keanggotaan fungsi Fuzzy. Sebuah contoh perbandingan penilaian siklus hidup dari empat proses pengolahan limbah disajikan dalam penelitian 
tersebut. Hasil penelitian menunjukkan bahwa teknik analisis multi kriteria dapat diterapkan secara sukses untuk melakukan pembobotan dan sensitivitas analisis dalam penilaian siklus hidup (Agarski et al., 2015).

Beberapa atribut pengambilan keputusan, yaitu, sistem pembobotan secara sederhana untuk memecahkan masalah pemilihan lokasi fasilitas dengan menggunakan tujuan / atribut subjektif pada kelompok pengambilan keputusan. Sistem yang diusulkan mengintegrasikan teori himpunan fuzzy, sistem rating factor dan pembobotan sederhana $(S A W)$ untuk mengevaluasi lokasi fasilitas alternatif. $S A W$ diterapkan untuk menangani kedua dimensi kualitatif dan kuantitatif. Proses $S A W$ mempertimbangkan pentingnya setiap pembuat keputusan, dan total skor untuk lokasi alternatif kemudian diturunkan oleh kelompok homo/ kelompok heterogen dalam pengambil keputusan (Chou et al., 2008).

Metode pembobotan sederhana $(S A W)$ merupakan pendekatan yang paling populer untuk beberapa pengambilan keputusan, tidak praktis lagi jika informasi yang digunakan masih samar. SAW berlaku untuk defuzzifikasi yang mendistorsi angka fuzzy. Sebagian besar metode biasanya membutuhkan waktu yang panjang dan manipulasi data yang melelahkan. Dalam penelitian mengembangkan metode baru pembobotan sederhana yang masih samar untuk beberapa atribut pengambilan keputusan. Pemeringkatan dilakukan dengan konsep rasio preferensi yang membandingkan bilangan fuzzy yang berpasangan. Metode ini memberikan skor penilaian untuk alternatif, yang praktis dan lebih realistis (Modarres dan Sadi, 2005).

RFID merupakan teknologi compact wireless yang diunggulkan untuk mentransformasi dunia komersial. RFID memanfaatkan frekuensi radio untuk identifikasi otomatis terhadap obyek-obyek atau manusia. Kenyataan bahwa manusia amat terampil dalam mengidentifikasi obyek-obyek dalam kondisi lingkungan yang berbeda-beda menjadi motivasi dari teknologi ini. Sebagai contoh, seseorang yang mengantuk dapat dengan mudah mengambil secangkir kopi di atas meja sarapan yang berantakan di pagi hari. Sementara itu komputer sangatlah lemah dalam melakukan tugastugas demikian. RFID dapat dipandang sebagai suatu cara untuk pelabelan obyek-obyek secara eksplisit untuk memfasilitasi hal tersebut dengan menggunakan peralatan-peralatan komputer. RFID adalah teknologi penangkapan data yang dapat digunakan secara elektronik untuk mengidentifikasi, melacak dan menyimpan informasi yang tersimpan dalam tag RFID.

Sistem RFID terdiri dari tiga komponen, meliputi :

a. RFID Tag merupakan peralatan (device) yang menyimpan informasi untuk identifikasi objek. RFID tag sering juga disebut sebagai transponder.
Tag yang digunakan pada penelitian ini adalah tag bertipe kartu seukuran kartu nama.

b. Tag Reader: merupakan peralatan device yang kompatibel dengan RFID tag yang akan berkomunikasi secara wireless dengan tag reader. Tag yang digunakan pada penelitian ini adalah tag dengan jarak baca pendek tipe $R F-100$.

c. Enterprise System merupakan sistem pada sebuah workstation atau PC yang dapat membaca data dari tag melalui pembaca RFID. Baik tag dan pembaca $R F I D$ diperlengkapi dengan antena sehingga dapat menerima dan memancarkan gelombang elektromagnet.

Arsitektur sistem RFID dalam sistem monitoring diberikan pada Gambar 1 :

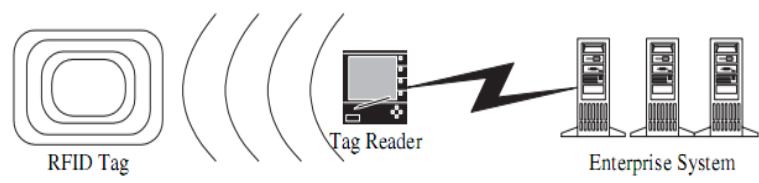

Gambar 1. Arsitektur Sistem RFID (Roberts, 2006)

\subsection{Simple additive weighting}

Simple additive weighting (SAW) merupakan metode penjumlahan terbobot dari kinerja pada setiap alternatif pada semua kriteria. Metode $S A W$ mengenal adanya 2 (dua) atribut yaitu kriteria keuntungan (benefit) dan kriteria biaya (cost). Perbedaan mendasar dari kedua kriteria ini adalah dalam pemilihan kriteria ketika mengambil keputusan. Langkah-langkah penyelesaian dalam menggunakannya adalah sebagai berikut:

a. Menentukan alternatif, yaitu Ai.

b. Menentukan kriteria yang akan dijadikan acuan dalam pengambilan keputusan, yaitu $\mathrm{Cj}$.

c. Memberikan nilai rating kecocokan setiap alternatif pada setiap kriteria.

d. Menentukan bobot preferensi atau tingkat kepentingan (W) setiap kriteria:

$$
W=[W 1, W 2, W 3, \ldots, W J]
$$

e. Membuat tabel rating kecocokan dari setiap alternatif pada setiap kriteria.

f. Membuat matrik keputusan (X) yang dibentuk dari tabel rating kecocokan dari setiap alternatif pada setiap kriteria. Nilai X setiap alternatif (Ai) pada setiap kriteria $(\mathrm{Cj})$ yang sudah ditentukan,dimana, $\mathrm{i}=1,2, \ldots \mathrm{m}$ dan $\mathrm{j}=1,2, \ldots \mathrm{n}$.

$$
X=\left[\begin{array}{cccc}
x_{11} & x_{12} & \ldots & x_{1 j} \\
\cdot & & & \cdot \\
\cdot & & & \cdot \\
\cdot & & & \cdot \\
x_{i 1} & x_{i 2} & \ldots & x_{i j}
\end{array}\right]
$$

Melakukan normalisasi matrik keputusan dengan cara menghitung nilai rating kinerja ternomalisasi (rij) dari alternatif Ai pada kriteria $\mathrm{Cj}$. 


$$
r_{i j}=\left\{\begin{array}{l}
\frac{x_{i j}}{\operatorname{Max}_{i}\left(x_{i j}\right)} \\
\frac{\operatorname{Min}_{i} x_{i j}}{x_{i j}}
\end{array}\right.
$$

Kriteria keuntungan apabila nilai memberikan keuntungan bagi pengambil keputusan, sebaliknya kriteria biaya apabila menimbulkan biaya bagi pengambil keputusan. Apabila berupa kriteria keuntungan maka nilai dibagi dengan nilai dari setiap kolom, sedangkan untuk kriteria biaya, nilai dari setiap kolom dibagi dengan nilai.

8. Hasil dari nilai rating kinerja ternomalisasi (rij) membentuk matrik ternormalisasi (R) .

$$
R=\left[\begin{array}{cccc}
r_{11} & r_{12} & \ldots & r_{1 j} \\
\cdot & & & \cdot \\
\cdot & & & \cdot \\
\cdot & & & \cdot \\
r_{i 1} & r_{i 2} & \ldots & r_{i j}
\end{array}\right]
$$

9. Hasil akhir nilai preferensi (Vi) diperoleh dari penjumlahan dari perkalian elemen baris matrik ternormalisasi (R) dengan bobot preferensi (W) yang bersesuaian eleman kolom matrik (W).

$$
V_{i}=\sum_{j=1}^{n} W_{j} r_{i j}
$$

Hasil perhitungan nilai Vi yang lebih besar mengindikasikan bahwa alternatif Ai merupakan alternatif terbaik

\section{Metodologi}

\subsection{Data dan pengolahan data}

Data yang digunakan dalam penelitian ini adalah data masuk dosen ke ruang kuliah, keluar dosen dari ruang kuliah, jumlah absensi kehadiran dosen, status kehadiran dosen, dan tingkat konsistensi perkuliahan dosen. Data yang telah dikumpulkan akan dilakukan proses pengolahan dengan menggunakan metode $S A W$ dan teknologi RFID(Akpinar dan Kaptan, 2010). Bagian ini bertujuan untuk menganalisa dan memahami teknik yang akan digunakan dalam pengolahan data yang telah diperoleh dan tempat penelitian, terutama pada proses, terdapat beberapa teknik yang digunakan untuk pengolahan data dengan $S A W$. Metode $S A W$ ini memecah-mecah suatu situasi yang kompleks, tidak terstruktur, ke dalam bagianbagian secara lebih terstruktur, mulai dari goals ke objectives, kemudian ke sub-objectives lalu menjadi alternatif tindakan.

Dta dihasilkan dari pembacaan tag RFID dan $R F I D$ reader dari data aktivitas perkuliahan di ruang kuliah. Peralatan yang digunakan dalam simulasi berupa perangkat keras yaitu: RFID dan komputer. Perangkat lunak yang digunakan diantaranya $P H P$ versi 5.2.9 yang bekerja di sistem operasi windows seven 32 bit dan $M y$ SQL sebagai manajemen database. Spesifikasi perangkat keras yang diperlukan adalah Laptop dengan Axioo Core 2 Duo, Hardisk $250 \mathrm{~GB}$, Memori $1 \mathrm{~GB}$, dan RFID berupa short range reader yang bekerja dengan jarak pembacaan antara 1 sampai 5 centimeter, format kartu pasif. Sedangkan spesifikasi perangkat lunak untuk mengembangkan, membaca perangkat keras RFID dan pengolahan database menggunakan $P H P$ versi 5.2.9 dengan menggunakan database My SQL.

\subsection{Prosedur Penelitian}

Sistem perangkingan tingkat kedisiplinan dosen berdasarkan monitoring kehadiran perkuliahan saat ini masih menggunakan sistem dokumentasi manual untuk pengawasan dan pelaporannya. Data kehadiran absensi manual diperoleh petugas lapangan dengan mendatangai satu persatu dosen yang mengajar di ruang kuliah. Pada setiap akhir sesi perkuliahan petugas melakukan rekapitulasi data dan begitu seterusnya setiap hari, setiap minggu sampai setiap akhir semester perkuliahan. Pimpinan bisa meminta laporan secara berkala berdasarkan hasil rekapitulasi manual data yang dibuat oleh petugas lapangan. Prosedur dan kerangka kerja pen elitian seperti yang terlihat pada Gambar 2.

Sistem ini memiliki kelemahan pekerjaan menumpuk pada bagian petugas pendataan yang melakukan rekapitulasi data bila dilakukan secara manual dan proses pelaporan menjadi lama. Pengecekan dosen yang tidak hadir tidak dapat dilakukan saat itu juga. Dengan menggunakan RFID, kualitas dan kecepatan pelaporan (reporting) dapat ditingkatkan. Laporan tentang kehadiran dosen dapat diketahui secara real-time dari server pusat, baik secara online ataupun menggunakan metode sinkronisasi data.

Petugas dapat mengakses data pada seluruh ruang kuliah untuk mendapatkan laporan up-to-date mengenai kehadiran dosen. Petugas bisa mengurangi permasalahan monitoring kehadiran dosen yang sering mengakibatkan kesalahan pencatatan dan dapat mengurangi kepercayaan dan kepuasan dosen dan pimpinan. Hal ini dimungkinkan karena kehadiran dosen dapat dengan mudah dipantau untuk mendapatkan data yang akurat tentang suatu hasil tertentu pada waktu tetentu, yang kemudian dihubungkan dengan sistem pengawasan secara keseluruhan. Teknologi ini juga memungkinkan pimpinan untuk menganalisa tingkat kedisiplinan dosen pada suatu program studi dan juga melakukan analisa kehadiran perprogram studi, sehingga pimpinan bisa memberikan penghargaan dan hukuman kepada dosen pada program studi tertentu.

Analisa sistem dilakukan secara langsung pada suatu program studi. Berdasarkan hasil analisis yang telah dilakukan maka didapatkan bahwa pada suatu program studi banyak terdapat dosen yang disiplin dalam melaksanakan perkuliahan, namun belum terdapat sebuah sistem untuk perangkingan tingkat kedisiplinan dosen yang dapat memberikan penghargaan terhadap dosen yang disiplin. Bukan hanya untuk dosen disiplin saja tetapi untuk dosendosen lainnya pula menjadi pemacu untuk lebih 
disiplin. Setelah melakukan pengamatan sistem yang sedang berjalan pada suatu program studi, diperoleh suatu gagasan untuk mengembangkan aplikasi perangkingan kedisiplinan dosen yang didalamnya akan terdapat sebuah proses perangkingan kedisiplinan dosen dalam kehadiran perkuliahan.

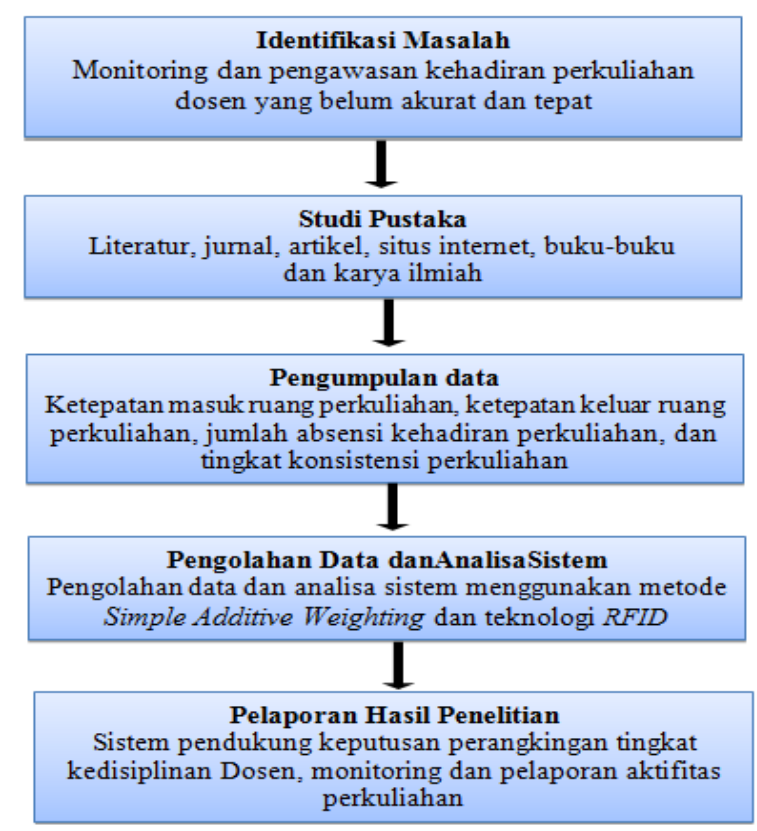

Gambar 2. Prosedur penelitian

Dalam pengembangannya aplikasi ini akan dibangun dengan ditambahkan metode penunjang keputusan perangkingan disiplin dosen, karena dalam aplikasi tersebut sudah terdapat elemen-elemen untuk penilaian/pemilihan dosen paling disiplin. Untuk perhitungan pemilihan dosen paling disiplin pada suatu program studi berbasis Fuzzy Multiple Attribute Decision Making (FMADM) dengan menggunakan metode $S A W$ adalah sebagai berikut :.

a. Menentukan kriteria yang digunakan untuk acuan pengambilan keputusan.

Kriteria untuk pengambilan keputusan perangkingan dosen disiplin di suatu perguruan tinggi adalah :

K1 = Ketepatan Masuk Ruang Kuliah

K2 = Ketepatan Keluar Ruang Kuliah

K3 = Absen Tanpa Keterangan / Mangkir

K4 = Jenis Kehadiran Perkuliahan

K5 = Tingkat Konsistensi Jadwal Mengajar

b. Menentukan rating kecocokan setiap alternatif pada setiap kiteria. Nilai dari rating kecocokan setiap alternatif pada kriteria perangkingan dosen disiplin didapat dari hasil observasi dan diskusi dengan pihak program studi.

c. Membuat matriks keputusan berdasarkan kriteria. Berikut beberapa kriteria dan bobotnya yang digunakan untuk melakukan perangkingan dosen disiplin pada suatu program studi. Nilai dari bobot setiap kriteria didapat dari hasil observasi dan diskusi dengan pihak program studi.

Kriteria Ketepatan Masuk Ruang Kuliah (K1). Kriteria ketepatan masuk ruang kuliah ini merupakan kriteria yang terdapat pada hasil record waktu masuk dari RFID. Kriteria ketepatan masuk ruang kuliah sesuai jadwal yang telah ditetapkan dimasukan karena dengan menggunakan waktu masuk kemungkinan terdapat nilai yang sama atau jumlah yang sama pada waktu masuk termasuk kecil kemungkinannya. Kriteria ketepatan masuk ruang kuliah diberikan pada Tabel 1.

Tabel 1. Kriteria ketepatan masuk ruang kuliah

\begin{tabular}{llc}
\hline Ketepatan Masuk Ruang Kuliah & Nilai \\
\hline $0-5$ & menit & 100 \\
$6-10$ & menit & 80 \\
$11-15$ & menit & 60 \\
$16-20$ & menit & 40 \\
$21-30$ & menit & 20 \\
$>30$ & menit & 0 \\
\hline
\end{tabular}

Tabel 2 Kriteria ketepatan keluar ruang kuliah

\begin{tabular}{ccc}
\hline Ketepatan Keluar Ruang Kuliah & Nilai \\
\hline $0-5$ & menit & 100 \\
$6-10$ & menit & 80 \\
$11-15$ & menit & 60 \\
$16-20$ & menit & 40 \\
$21-30$ & menit & 20 \\
$>30$ & menit & 0 \\
\hline
\end{tabular}

Kriteria Ketepatan Keluar Ruang Kuliah (K2). Kriteria ketepatan keluar ruang kuliah ini merupakan kriteria yang terdapat pada hasil record waktu keluar dari RFID. Kriteria ketepatan keluar ruang kuliah sebelum jadwalnya dimasukan karena dengan menggunakan waktu keluar kemungkinan terdapat nilai yang sama atau jumlah yang sama pada waktu keluar termasuk kecil kemungkinannya. Kriteria ketepatan keluar ruang kuliah dapat dilihat pada Tabel 2.

Kriteria Absen Tanpa Keterangan / Mangkir (K3). Kriteria Absen ini pula terdapat pada record hasil $R F I D$, kriteria absen yang dimaksud adalah jumlah mangkir/tanpa keterangan dosen dalam kehadiran. Sesuai dengan Standar Nasional Pendidikan Tinggi (Permendikbud nomor 49, 2014), semester merupakan satuan waktu kegiatan perkuliahan efektif selama 16 (enam belas) minggu. Kriteria absen dapat dilihat pada Tabel 3 .

Tabel 3. Kriteria Absen Tanpa Keterangan/Mangkir

\begin{tabular}{cc} 
Jumlah Absen & Nilai \\
Tanpa Keterangan & 100 \\
0 & 80 \\
1 & 60 \\
$2-3$ & 40 \\
$4-5$ & 20 \\
$6-7$ & 0 \\
$\geq 8$ & \\
\hline
\end{tabular}


Kriteria Jenis Kehadiran Perkuliahan (K4) Kriteria kehadiran perkualiahan tidak semuanya termasuk dalam record hasil RFID, merupakan kriteria yang bisa dimasukkan secara manual oleh admin tanpa RFID agar dapat diperoleh perangkingan tingkat kedisiplinan kehadiran dosen. Kriteria kehadiran dilihat pada Tabel 4.

Tabel 4 Kriteria Jenis Kehadiran Perkuliahan

\begin{tabular}{cc}
\hline Kehadiran & Nilai \\
\hline Hadir Sesuai Jadwal & 100 \\
Hadir Tidak Konsisten & 80 \\
Tugas Dinas Luar & 60 \\
Sakit & 40 \\
Izin Urusan Pribadi & 20 \\
Mangkir & 0 \\
\hline
\end{tabular}

Kriteria Konsistensi Jadwal Mengajar (K5). Kriteria konsistensi jadwal mengajar merupakan nilai sikap dosen selama melaksanakan perkuliahan. Tabel kriteria konsistensi jadwal mengajar dapat dilihat pada Tabel 5.

Tabel 5. Kriteria Konsistensi

\begin{tabular}{lc}
\hline Nilai Sikap Konsistensi & Nilai \\
\hline A (Sangat Tinggi $=\geq 7)$ & 100 \\
B (Tinggi $=5-6)$ & 80 \\
C (Cukup $=3-4)$ & 60 \\
D (Rendah $=1-2)$ & 40 \\
E (Sangat Rendah $=0)$ & 0 \\
\hline
\end{tabular}

Alternatif : Dosen $1=$ A1, Dosen $2=\mathrm{A} 2$, Dosen $3=$ A3, Dosen 4 = A4;

Menetapkan nilai alternatif pada setiap kriteria berdasarkan bobot masing-masing kriteria. Nilaia alternative pada setaiap kriteria diberikan pada Tabel 6.

Tabel 6. Nilai Alternatif pada setiap kriteria

\begin{tabular}{cccccc}
\hline \multirow{2}{*}{ Alternatif } & K1 & K2 & K3 & K4 & K5 \\
\hline A1 & 0 & 0 & 100 & 80 & 0 \\
A2 & 98,75 & 100 & 100 & 100 & 100 \\
A3 & 96,25 & 100 & 100 & 100 & 100 \\
A4 & 93,75 & 100 & 100 & 100 & 100 \\
\hline
\end{tabular}

Berdasarkan alternatif alternatif yang ada berupa data dosen menggunakan beberapa kriteria yang telah ditentukan yaitu data ketepatan masuk dosen ke ruang kuliah, ketepatan keluar dosen dari ruang kuliah, jumlah absensi kehadiran dosen, status kehadiran dosen, dan tingkat konsistensi perkuliahan dosen akan diberikan pembobotan nilai. Kemudian ditetapkan matriks keputusan berdasarkan kriteria dan selanjutnya dilakukan normalisasi matriks berdasarkan persamaan yang disesuaikan dengan jenis atribut sehingga diperoleh matriks ternormaliasasi:

$$
X=\left[\begin{array}{ccccc}
0 & 0 & 100 & 80 & 0 \\
98,75 & 100 & 100 & 100 & 100 \\
96,25 & 100 & 100 & 100 & 100 \\
93,75 & 100 & 100 & 100 & 100
\end{array}\right]
$$

Setelah dijadikan matriks kemudian nilai matriks di atas di normalisasikan :

$$
\mathrm{R}=\left[\begin{array}{ccccc}
0 & 0 & 1 & 0,8 & 0 \\
1 & 1 & 1 & 1 & 1 \\
0,97 & 1 & 1 & 1 & 1 \\
0,95 & 1 & 1 & 1 & 1
\end{array}\right]
$$

Proses perangkingan dilakukan melalui penjumlahan dari perkalian matrik ternormalisasi $\mathrm{R}$ dengan vektor bobot sehingga diperoleh nilai terbesar yang dipilih sebagai alternatif terbaik sebagai solusi. Selanjutnya dilakukan perangkingan untuk mencari alternatif terbaik untuk tingkat kedisiplinan dosen dengan cara melakukan penilaian bobot preferensi. Nilai bobot preferensi $(w)$ / vektor bobot didapat dari nilai bobot setiap kriteria yang dipresentasikan dari jumlah penilaian $100 \%$ yang dibagi atas 5 kriteria dengan tingkat kepentingan kriteria yang berbeda. Langkah terakhir adalah dengan menghitung hasil akhi rnilai preferensi (Vi) untuk mencari alternatif terbaik untuk tingkat kedisiplinan dosen dengan menjumlahkan perkalian nilai bobot preferensi (w) dikalikan nilai matriks normalisasi (r) pada setiap alternatif. Setelah perhitungan dilakukan dengan menggunakan 4 alternatif maka didapat alternatif terbaik untuk tingkat kedisiplinan dosen.

\subsection{Kerangka Sistem Informasi}

Kerangka sistem monitoring perkuliahan dengan metode SAW dan teknologi RFID diberikan pada Gambar 3. Sistem monitoring perkulihaan menggunakan input data hasil perekaman dari RFID yang disimpan dalam basis data komputer. Basis data yang berisi alternatif beberapa orang dosen akan diolah menjadi lima kriteria yang telah ditentukan yang selanjutnya akan diproses dengan metode SAWuntuk mendapatkan output monitoring aktivitas perkuliahan secara real time, perangkingan tingkat kedisiplinan kehadiran perkuliahan dosen dan laporan aktivitas perkuliahan dosen.

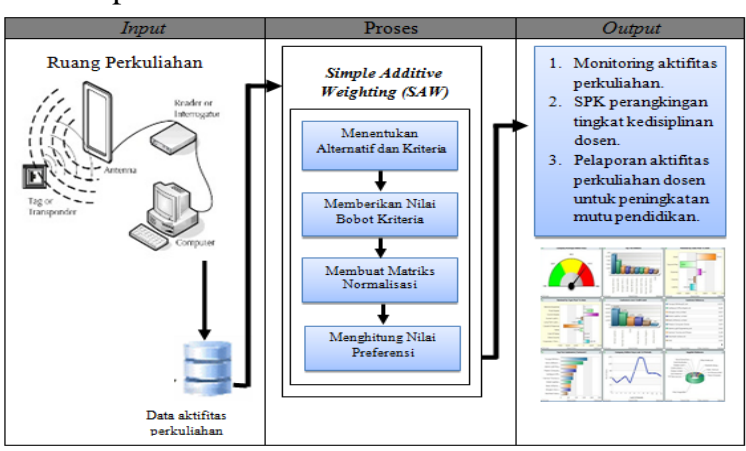

Gambar 3. Kerangka sistem monitoring perkulihan

\section{Hasil dan Pembahasan}

\subsection{Hasil Penelitian}

Sistem monitoring aktivitas perkuliahan didesain sebagai sistem yang real time menggunakan metode $n$ 
SAW dan RFID. Metode SAW digunakan untuk menetukan pembobotan dari setiap kriteria yang dilibatkan dalam sistem, sedangkan teknologi RFID digunakan secara elektronik untuk mengidentifikasi dan menyimpan informasi aktivitas perkuliahan. Metode SAW digunakan untuk analisis hasil monitoring secara real time aktivitas perkuliahan di ruangan perkuliahan, perangkingan tingkat kedisiplinan perkuliahan dosen pada masing-masing mata kuliah yang dijadwalkan, serta pelaporan aktivitas perkuliahan pada setiap mata kuliah yang telah dijadwalkan.

Tabel 7. Contoh data input kehadiaran

\begin{tabular}{|c|c|c|c|c|c|c|}
\hline $\begin{array}{l}\text { Kode } \\
\text { Absen }\end{array}$ & $\begin{array}{c}\text { Kode Kalender } \\
\text { Absensi }\end{array}$ & Kode Dosen & $\begin{array}{c}\text { Kriteria } \\
\text { Kehadiran } \\
\end{array}$ & $\begin{array}{l}\text { Waktu } \\
\text { Masuk }\end{array}$ & $\begin{array}{l}\text { Waktu } \\
\text { Keluar }\end{array}$ & $\begin{array}{c}\text { Kode Jadwal } \\
\text { Kuliah }\end{array}$ \\
\hline 47 & 2015-2016-S1-M1-H1 & 0001710001 & Hadir & $\begin{array}{c}2015-08-03 \\
08.05: 00\end{array}$ & $\begin{array}{c}2015-08-03 \\
09.45: 00\end{array}$ & TM-1112 \\
\hline 45 & 2015-2016-S1-M1-H1 & 0001712433 & Hadir & $\begin{array}{c}2015-08-03 \\
10.10: 00\end{array}$ & $\begin{array}{c}2015-08-03 \\
12.35: 00\end{array}$ & TM-1231 \\
\hline 49 & 2015-2016-S1-M1-H1 & 0001710002 & Hadir & $\begin{array}{c}2015-08-03 \\
10.15: 00\end{array}$ & $\begin{array}{c}2015-08-03 \\
12.35: 00\end{array}$ & TM-1232 \\
\hline 51 & 2015-2016-S1-M1-H1 & 0001758649 & Hadir & $\begin{array}{c}2015-08-03 \\
13.20: 00\end{array}$ & $\begin{array}{c}2015-08-03 \\
15.35: 00\end{array}$ & TM-1351 \\
\hline 52 & 2015-2016-S1-M1-H1 & 0001710003 & Hadir & $\begin{array}{c}2015-08-03 \\
13.25: 00\end{array}$ & $\begin{array}{c}2015-08-03 \\
15.35: 00\end{array}$ & TM-1352 \\
\hline 53 & 2015-2016-S1-M1-H1 & 0001714293 & Hadir & $\begin{array}{c}2015-08-03 \\
16.35: 00\end{array}$ & $\begin{array}{c}2015-08-03 \\
17.45: 00\end{array}$ & TM-1471 \\
\hline 54 & 2015-2016-S1-M1-H1 & 0001710004 & Hadir & $\begin{array}{c}2015-08-03 \\
16.40: 00\end{array}$ & $\begin{array}{c}2015-08-03 \\
17.45: 00\end{array}$ & TM-1472 \\
\hline
\end{tabular}

Implementasi sistem dilakukan sesuai dengan perancangan dalam penerapan SAWuntuk monitoring aktivitas perkuliahan yang telah dilakukan dengan teknologi DFD. Implementasi sistem untuk monitoring aktivitas perkuliahan memiliki dua belas input dan empat tahapan proses untuk menghasilkan secara real time aktivitas perkuliahan di ruangan perkuliahan, perangkingan tingkat kedisiplinan perkuliahan dosen pada masing-masing mata kuliah yang dijadwalkan, serta pelaporan aktivitas perkuliahan pada setiap mata kuliah yang telah dijadwalkan. Contoh data input kehadiaran pada sistem monitoring perkulihan diberikan pada Tabel 7.

Media input dirancang dan digunakan untuk memasukan data-data master yang akan digunakan untuk media proses dalam monitoring aktivitas perkuliahan dan mengkonfigurasi setting nilai data awal. M media input dalam monitoring aktivitas perkuliahan :

a. Input absensi ruangan.

Input absensi ruangan merupakan media untuk memasukkan data absensi ruangan yang digunakan secara otomatis dari perekaman RFID. Input absensi ruangan memiliki atribut kode kelas, hari, nama dosen, waktu jadwal masuk, waktu jadwal keluar, waktu hadir masuk dan waktu hadir keluar. Atribut waktu hadir masuk dan atribut waktu hadir keluar dipergunakan sebagai bobot nilai dalam proses pembentukan matriks normalisasi dan penghtungan nilai preferensi.

b. Input absensi manual.

Input absensi manual merupakan media untuk memasukkan data absensi manual yang didapat dari pengisian data secara manual oleh admin. Input absensi manual memiliki atribut kode absen, kode kalender absensi, kode dosen, kriteria kehadiran, waktu masuk, waktu keluar, dan kode jadwal kuliah.
Atribut kriteria kehadiran, atribut waktu masuk dan atribut waktu keluar dipergunakan sebagai bobot nilai dalam proses pembentukan matriks normalisasi dan penghtungan nilai preferensi.

Media proses merupakan media untuk melakukan proses yang melibatkan dari beberapa data master dan menghasilkan suatu output yang sudah ditentukan sesuai kerangka sistem. Proses menentukan kriteria dan alternatif merupakan media proses untuk menentukan data-data kriteria dan alternatif yang akan digunakan dalam proses pembentukan matriks normalisasi dan penghitungan nilai preferensi.

c. Proses memberikan nilai bobot pada masingmasing kriteria

Proses memberikan nilai bobot pada masingmasing kriteria kriteria merupakan media proses untuk menentukan nilai masing-masing kriteria yang akan digunakan dalam proses pembentukan matriks normalisasi dan penghitungan nilai preferensi. Proses membuat matriks untuk normalisasi merupakan media proses untuk menentukan hasil matriks normalisasi dari masing-masing pembobotan kriteria pada setiap alternatif yang akan digunakan dalam proses penghitungan nilai preferensi. Hasil matriks normalisasi (R) didapat dari pembagian nilai bobot masing-masing kriteria pada setiap alternatif dengan nilai bobot maksimum dari keseluruhan alternatif.

Proses menghitung nilai preferensi merupakan media proses untuk menentukan hasil nilai preferensi (V) dari masing-masing kriteria pada setiap alternatif yang ada dengan cara mengalikan hasil matriks normalisasi (R) dengan bobot nilai kriteria (W) pada masing-masing kriteria pada setiap alternatif. Hasil keseluruhan nilai preferensi merupakan penjumlahan keseluruhan nilai preferensi masing-masing kriteria pada setiap alternatif. 
Media output merupakan media hasil dari proses penghitungan dan pembobotan kriteria untuk perangkingan dengan metode SAW untuk menghasilkan suatu output dari sistem monitoring. Contoh output hasil monitoring aktivitas perkulihan diberikan pada Tabel 8. Output monitoring aktivitas perkuliahan merupakan media untuk memonitoring aktivitas perkuliahan yang ada di ruang perkuliahan mengetahui dosen dalam status hadir atau tidak hadir.

Tabel 8. Contoh output monitoring aktivitas perkuliahan

\begin{tabular}{|c|c|c|c|c|c|c|c|}
\hline Kode Jurusan & Kode Kelas & Hari & $\begin{array}{l}\text { Waktu } \\
\text { Jadwal } \\
\text { Masuk }\end{array}$ & $\begin{array}{l}\text { Waktu } \\
\text { Jadwal } \\
\text { Keluar }\end{array}$ & $\begin{array}{l}\text { Waktu Hadir } \\
\text { Masuk }\end{array}$ & $\begin{array}{l}\text { Waktu Hadir } \\
\text { Keluar }\end{array}$ & KET \\
\hline 171-TM & TM-1231 & Senin & 10:00:00 & $12: 30: 00$ & $\begin{array}{c}2015-08-03 \\
10.10: 00\end{array}$ & $\begin{array}{c}2015-08-03 \\
12.35: 00\end{array}$ & Hadir \\
\hline 171-TM & TM-1232 & Senin & 10:00:00 & $12: 30: 00$ & $\begin{array}{c}2015-08-03 \\
10.15: 00\end{array}$ & $\begin{array}{c}2015-08-03 \\
12.35: 00\end{array}$ & Hadir \\
\hline 171-TM & TM-1351 & Senin & 13:00:00 & $15: 30: 00$ & $\begin{array}{c}2015-08-03 \\
13.20: 00\end{array}$ & $\begin{array}{c}2015-08-03 \\
15.35: 00\end{array}$ & Hadir \\
\hline 171-TM & TM-1352 & Senin & 13:00:00 & $15: 30: 00$ & $\begin{array}{c}2015-08-03 \\
13.25: 00\end{array}$ & $\begin{array}{c}2015-08-03 \\
15.35: 00\end{array}$ & Hadir \\
\hline 171-TM & TM-1471 & Senin & 16:00:00 & $17: 40: 00$ & $\begin{array}{c}2015-08-03 \\
16.35: 00\end{array}$ & $\begin{array}{c}2015-08-03 \\
17.45: 00\end{array}$ & Hadir \\
\hline 171-TM & TM-1472 & Senin & 16:00:00 & $17: 40: 00$ & $\begin{array}{c}2015-08-03 \\
16.40: 00\end{array}$ & $\begin{array}{c}2015-08-03 \\
17.45: 00\end{array}$ & Hadir \\
\hline 171-TM & TM-1111 & Senin & 08:00:00 & 09:40:00 & $\begin{array}{c}0000-00-00 \\
00.00: 00\end{array}$ & $\begin{array}{c}0000-00-00 \\
00.00: 00\end{array}$ & $\begin{array}{l}\text { Hadir Tidak } \\
\text { Konsisten }\end{array}$ \\
\hline
\end{tabular}

Output dari sistem pengambilan keputusan (SPK) perangkingan tingkat kedisiplinan dosen merupakan media untuk melakukan perangkingan tingkat kedisiplinan dosen dalam satu semester perkuliahan secara keseluruhan dan per masing-masing jurusan. Output ini diperoleh setelah melakukan perangkingan hasil nilai preferensi secara keseluruhan pada proses penghitungan SAW dari masing-masing kriteria pada setiap alternatif yang ada. Output SPK perangkingan kehadiran dosen diberikan pada Gambar 4. Gambar 4 memberikan hasil perankingan kehadiran dosen yang menunjukan kedisiplinan dosen.
Output pelaporan aktivitas perkuliahan merupakan media untuk menampilkan statistik pelaporan aktivitas perkuliahan masing-masing kelas pada setiap dosen yang bertanggungjawab terhadap kelas tersebut dalam satu semester perkuliahan secara keseluruhan dan per masing-masing jurusan. (Gambar 5). Gambar 5 memperlihatkan tingkat kehadiran dan tingkat ketidak hadiran dosen perkuliah. Hasil dari output ini menjadi bahan pengambilan keputusan bagi pimpinan dalam manajemen pembelajaran di setiap jurusan.

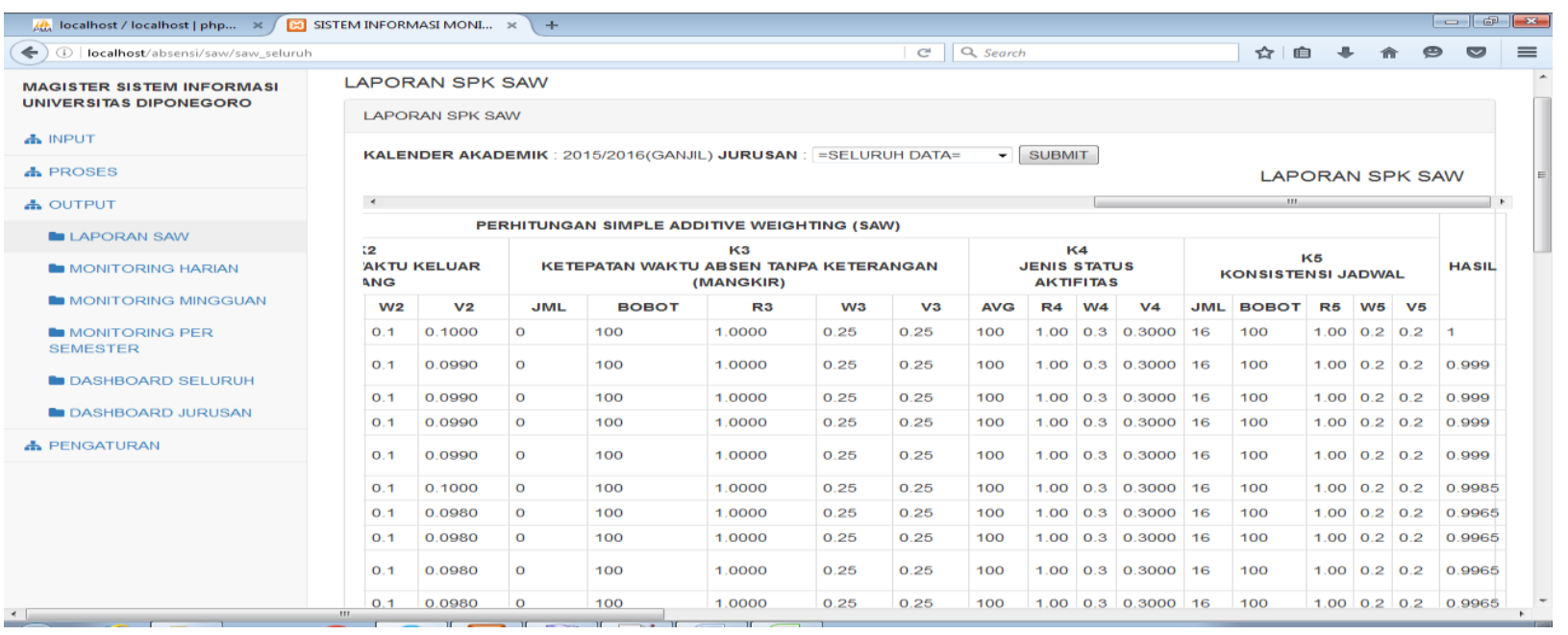

Gambar 4. Output SPK Perangkingan tingkat kehadiran dosen. 


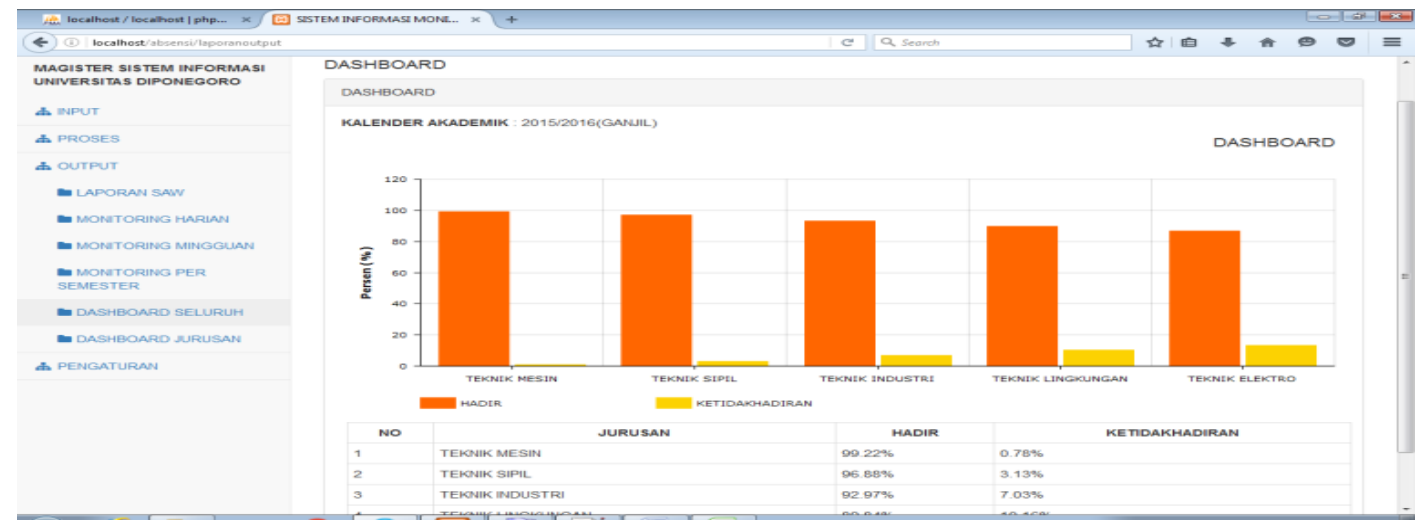

Gambar 5. Output Pelaporan Aktivitas Perkuliahan Dosen

\subsection{Pembahasan}

Sistem yang dibangun memakai input dari setiap dosen yang menggunakan tag RFID saat masuk / keluar ruang perkuliahan. Monitoring aktivitas perkuliahan secara real time dilakukan dengan menggunakan RFID sehingga pada sistem dapat dilihat status kehadiran dosen, waktu masuk dan waktu keluar. Kemudian status kehadiran dosen ini menjadi salah satu variabel untuk pembobotan kriteria yang dilakukan menggunakan Simple Additive Weighting $(S A W)$. Hasil dari SAW berupa perangkingan tingkat kedisiplinan perkuliahan dosen.

Penelitian dilakukan dengan menggunakan data sampel yaitu menggunakan 40 (empat puluh) dosen dengan 20 (dua puluh) matakuliah serta 40 (empat puluh) kelas pada 5 (lima) jurusan dengan rincian : 8 (delapan) dosen dengan 4 (empat) matakuliah serta 8 (delapan) kelas untuk masing-masing jurusannya, 2 (dua) kelas paralel untuk masing-masing matakuliah pada setiap jurusannya. Data sampel yang digunakan pada penghitungan Simple Additive Weighting (SAW) untuk monitoring aktivitas perkuliahan menampilkan secara real time aktivitas perkuliahan di ruangan perkuliahan, perangkingan tingkat kedisiplinan perkuliahan dosen pada masing-masing mata kuliah yang dijadwalkan, serta pelaporan aktivitas perkuliahan pada setiap mata kuliah yang telah dijadwalkan adalah periode semester ganjil tahun akademik 2015/2016 atau sepanjang rentang 3 agustus s/d 7 desember 2015. Penghtitungan Simple Additive Weighting $(S A W)$ dilakukan dengan menggunakan pembobotan kriteria dari 5 macam pengkondisian yang sering terjadi pada saat aktivitas perkuliahan berlangsung yaitu kriteria ketepatan waktu masuk, kriteria ketepatan waktu keluar, kriteria absen tanpa keterangan/mangkir, kriteria jenis aktivitas perkuliahan, dan kriteria konsisten kehadiran sesuai jadwal.

Informasi yang didapat dari hasil monitoring perkuliahan adalah laporan aktivitas perkuliahan dosen pada periode semester ganjil tahun akademik 2015/2016 untuk dosen dengan kode RFID 1712433 dengan nilai $\mathrm{V} 1=0,15 ; \mathrm{V} 2=0,1 ; \mathrm{V} 3=0,25 ; \mathrm{V} 4=$ 0,$3 ; \mathrm{V} 5=0,2$ didapat nilai preferensi 1 dan dalam perangkingan akan berada di nilai tertinggi / rangking terbaik sedangkan dosen dengan kode RFID 1750001 dengan nilai $\mathrm{V} 1=0,066 ; \mathrm{V} 2=0,044 ; \mathrm{V} 3=0 ; \mathrm{V} 4$ $=0,132 ; \mathrm{V} 5=0,2$ didapat nilai preferensi 0,442 dan dalam perangkingan akan berada di nilai terendah / rangking terbawah.

\section{Kesimpulan}

Sistem monitoring perkulihan dapat dilakukan untuk evaluasi dan analisis aktivitas perkulihan. Ouput sistem monitoring perkuliahan menjadi bahan pengambilan keputusan untuk perbaikan aktivitas perkualihan atau pembelajaran di masing-masing juruan sesuai dengan hasil dari analisis menggunakan metode SAW, dengan input data yang didapatkan menggunakan teknologi RFID.

SAW memiliki kelebihan penghitungan pembobotan matematis sederhana yang menghasilkan perangkingan tingkat kedisiplinan dosen. RFID mengefektifkan perekaman data aktivitas perkuliahan guna menghasilkan laporan kehadiran perkuliahan dosen pada masing-masing kelas secara real time.

Hasil perangkingan dengan menggunakan SAW menjadi salah satu bahan pertimbangan pimpinan dalam mengevaluasi kedisiplinan dan tingkat produktifitas kinerja dosen serta membantu pengambilan keputusan berkaitan dengan manajemen perkuliahan. Disamping itu hasil monitoring juga dapat membantu pimpinan dalam mengambil keputusan dengan cepat berdasarkan data yang akurat terhadap penggantian dosen yang tidak hadir serta kurang produktif dengan dosen pengganti yang sebidang keahliannya agar tidak terjadi penumpukan beban perkuliahan pada akhir periode semester perkuliahan.

\section{Daftar Pustaka}

Agarski, B., Budak, I., Vukelic, D., Hodolic, J., 2015. Fuzzy multi-criteria-based impact category weighting in life cycle assessment, Journal of Cleaner Production 33, 1- 11. 
Akpinar, S., Kaptan, H., 2010. Computer aided school administration system using RFID technology, Journal of Procedia Social and Behavioral Sciences 2, $4392-4397$.

Bazhenov, R., Bazhenova, N., Khilchenko, L., Romanova, M., 2015. Components of Education Quality Monitoring : Problems and Prospects, Journal of Procedia - Social and Behavioral Sciences 214, $103-111$.

Chang, T.H., Hsu, S.C., Wang, T.C., 2013. A proposed model for measuring the aggregative risk degree of implementing an RFID digital campus system with the consistent fuzzy preference relations, Journal of Applied Mathematical Modelling 37, 2605 - 2622.

Chou, S.Y., Chang, Y.H., Shen, C.Y., 2008. A fuzzy simple additive eighting system under group decision-making for facility location selection with objective/subjective attributes, Journal of Operational Research 189, 132 - 145.

Daraioa, C., Bonaccorsi, A., Simar, L., 2015. Rankings and university performance : A conditional multidimensional approach, European Journal of Operational Research 244, $918-930$.
Gladysz, B., Santarek, K., 2015. An assessment of technologies with wide range of impact. A case of RFID, Journal of Procedia Manufacturing 3, 1966 - 1973.

Glushak, N., Katkow, Y., Glushak, O., Katkowa, E., Kovaleva, N., 2015. Contemporary Economic Aspects of Education Quality Management at the University, Journal of Procedia - Social and Behavioral Sciences 214, $252-260$.

Modarres, M., Sadi-Nezhad, S., 2005. Fuzzy Simple Additive Weighting Method by Preference Ratio, Journal of Intelligent Automation and Soft Computing 11 (4), 235 - 244.

Oztaysi, B., Baysan, S., Akpinar, F., 2009. Radio frequency identification (RFID) in hospitality, Journal of Technovation 29, 618-624.

Roberts, C.M., 2006. Radio Frequency Identification (RFID), Journal of Computers \& Security 25, 18 -26 .

Wang, Y.J., 2015. A fuzzy multi-criteria decisionmaking model based on simple additive weighting method and relative preference relation, Journal of Applied Soft Computing 30, $412-420$ 